Turkish Online Journal of Qualitative Inquiry (TOJQI)

Volume 9, Issue 4, October 2018: 312-341

DOI: $10.17569 /$ tojqi.357497

Research Article

\title{
Comparing the Opinions and Practices of Preschool Teachers' about the Use of Natural Mathematics Language ${ }^{1}$
}

\author{
Zehra Saadet Firat ${ }^{2}$, Çağlayan Dinçer ${ }^{3}$
}

\begin{abstract}
The aim of this study was to compare the practices and opinions of preschool teachers on using natural mathematics language. The study group consisted of totally eight preschool teachers (five preschool teachers working at official independent kindergartens and three preschool teachers working at kindergartens of primary schools) in the central district of Erzurum province, Turkey. In order to conduct the study; all the teaching processes of teachers except for the mathematics activities were recorded using a camera in the classroom environment for a week and their anecdotes were recorded. At the end of observation, each teacher was interviewed and asked semi-structured questions prepared by the researchers of this study. Data obtained from the camera records were analyzed by using The Observer XT - Noldus software. Interview forms were analyzed by means of descriptive analysis method and similar responses were collected under the same themes. Teachers stated that they used natural mathematics language in their responses to interview questions but it was determined in line with the observation results that they did not use natural mathematics language. According to the observational data, it was determined that teachers frequently used giving instructions and drawing attention strategies and that the mathematical expressions teachers used mostly at times aside from the mathematics activities were related to counting-numbers, measuring, location in space and comparing skills. It was also determined that all of the teachers had a common decision that using mathematics language in the classroom environment would support the mathematical development of children.
\end{abstract}

Keywords: Preschool teacher, natural mathematics language, mathematical education, mathematics in preschool.

\footnotetext{
${ }^{1}$ This study includes a chapter written by the first author of the thesis.

${ }^{2}$ Res.Asst., Atatürk University, Kazım Karabekir Education Faculty, Department of Primary Education, Preschool Education Program, zehra.ozdemir@atauni.edu.tr, https://orcid.org/0000-0002-6893-3427

${ }^{3}$ Prof.Dr., Ankara University, Faculty of Educational Sciences, Department of Primary Education, Preschool Education Program, cdincer@education.ankara.edu.tr, https://orcid.org/0000-0001-5468-9155
} 


\title{
Okul Öncesi Öğretmenlerinin Doğal Matematik Dilini Kullanımlarına İlişkin Uygulamaları ile Görüşlerinin Karşılaştırılması
}

\begin{abstract}
$\ddot{O} z$
Bu çalışmada okul öncesi öğretmenlerinin doğal matematik dilini kullanımlarına ilişkin görüşleri ile uygulamalarının karşılaştırılması amaçlanmıştır. Erzurum ili merkezinde bulunan resmi bağımsız anaokullarından beş ve resmi ilkokul bünyesindeki anasınıflarından üç olmak üzere toplamda sekiz gönüllü okul öncesi öğretmeni çalışma grubunu oluşturmuştur. Çalışma için öğretmenlerin sınıf ortamında bir hafta boyunca matematik etkinlikleri dışındaki tüm öğretim süreçleri gözlemlenerek kameraya kaydedilmiş ve anekdot kayıtları alınmıştır. Gözlem sonunda her öğretmenle birer görüşme yapılmış ve araştırmacılar tarafından hazırlanmış yarı yapılandırılmış sorular sorulmuştur. Kamera kayıtlarından elde edilen veriler The Observer XT-Noldus programı ile analiz edilmiştir. Görüşme formlanı ise betimsel analiz yöntemiyle incelenmiş ve benzer yanıtlar aynı temalar altında toplanmıştır. Öğretmenlerin görüşme sorularına verdikleri yanıtlarda; doğal matematik dilini kullandıklarını ifade etmelerine karşın gözlem sonuçlarına göre kullanmadıkları belirlenmiştir. Gözlem verilerine göre öğretmenlerin matematik etkinlikleri dışındaki zamanlarda en fazla kullandıkları matematiksel ifadelerin, sayma-sayı, ölçme, mekanda konum ve karşılaştırma becerileriyle ilgili olduğu ve öğretmenlerin sıklıkla yönerge verme ve dikkat çekme stratejilerini kullandıkları belirlenmiştir. Öğretmenlerin tamamının, sınıf ortamında doğal matematik dili kullanmanın çocukların matematiksel gelişimlerini destekleyeceği konusunda ortak bir karara sahip oldukları saptanmıştır.
\end{abstract}

Anahtar Sözcükler: Okul öncesi öğretmeni, doğal matematik dili, matematik eğitimi, okul öncesinde matematik. 


\section{Introduction}

Children in the preschool period go through a rapid cognitive, social and physical development. Supporting their development is ensured not only through a formal and planned education, but also through an informal education. Formal methods are the activities, practices, expressions, and materials that teachers prepare and plan according to the developmental levels of children in order to achieve the learning outcomes determined within the educational process (Avc1, \& Dere, 2002). On the other hand, informal methods are the methods which arise as a result of the unconscious information exchange between children, which is unstructured and occur naturally and which depend on environmental and individual characteristics (Erdoğan, 2012).

Unlike the learning processes of adults, children acquire knowledge, learn and gain skills through plays, discoveries, and entertainment (Tuğrul, 2002). Every piece of information that children acquire during this period brings them different cognitive skills. Cognitive skills develop with mathematics. Children's first encounter with mathematics takes place through natural ways. From birth until the age of four, children experience a lot of mathematical stimuli in their surroundings (NCTM, 2000). Mathematics is not only a science that has formal representations and symbolic forms in children's life but it is also a wide field that represents a rich and flexible continuity from games to songs and TV programs (Moseley, 2005). The first mathematical experiences for children emerge as a process in which plays are run together with mathematics and in which curiosity and discovery feelings are dominant (Güven, Öztürk, Karataş, Arslan, \& Şahin, 2012; Linder, Powers-Costello, \& Stegelin, 2011).Towards the end of the early childhood period, it is seen that children know mathematical concepts and achieve basic mathematical skills (NAEYC, 2008; NCTM, 2000).

Teachers' forming robust mathematics basis for children during the preschool period can help children in later formal mathematics learnings (NCTM, 2000; Peter-Koop \& Scherer, 2012; Umay, 2003). According to NCTM (National Council for Mathematics Teachers), children are required to use mathematical language in order to express mathematics and establish a mathematical communication in a correct way (Ferrini-Mundy, 2000; Y1ldırım, 2012). The fact that children can express mathematics correctly and have acquired these skills is ensured through the opportunities that teachers offer them without creating an environment of anxiety and fear. The use of mathematical language by children and establishing a mathematical 
communication with appropriate words and concepts helps them to think creatively, to think about the concepts they use and to communicate effectively in a classroom environment (Kranda, 2008).

The role of teachers in mathematics teaching preschool period cannot be ignored. Teachers' use of mathematical language actively for the mathematical development of children and correct modeling of these children contribute to the mathematical development of children (NCTM, 2000). It is expected that teachers will lead children in acquiring mathematical skills and, thus, children's learning will be easier. The activities that teachers prepare for children and the way they communicate differ when the practices are formal or informal. The teacher who cannot use the correct language is likely to have difficulties in the classroom environment. The language, expressions, and contents used by teachers must be appropriate and correct for the levels of children (Klibanoff, Levine, Huttenlocher, Vasilyeva, \& Hedges, 2006). It is expected from teachers to use an appropriate tone, pronunciation, and emphasis in the classroom environment. The type of sentences they form, the content of the expressions and the way they address are perceived and modeled by children (Çetindağ, 2013).

Language and concept development of children affect their academic skills. Mathematical skills are associated with rich language experiences (Sarama, Lange, Clements, \& Wolfe, 2012; Uyanık \& Kandır, 2010). Children start to learn mathematical language by labeling objects. When children start to make sense of the concepts expressed by words, they also start to use it for the appropriate situations (as cited in Sarama et al., 2012). It is necessary that mathematical concepts and expressions should be used by teachers and children consciously, correctly and appropriately in activities in the classroom environment and children should be supported when these concepts and expressions are used by children. Mathematical language is important for children to communicate, to express their thoughts and talk with their peers or adults by choosing the conceptually correct words (Bali, 2002).

Natural mathematics language is the mathematical concepts, words, instructions, expressions, and sentences that preschool teachers use in a classroom environment (Klibanoff et al., 2006). It was agreed upon by the mathematics experts that natural mathematics language is necessary for mathematics teaching and it was included in mathematics standards determined for every each state in the United States of America (Bali, 2003; Kandır \& Orçan, 2010; Taştepe, 2012). 
The use of natural mathematics language has positive effects on counting, calculation and understanding symbols skills of children (Boonen, Kolkman, \& Kroesbergen, 2011; Mc Goron, 2010). Thanks to the mathematical language used in the classroom environment, it can be ensured that children understand the instructions more easily and mathematics can be made entertaining by means of reducing mathematical anxiety and prejudice levels (Taşkın \& Tuğrul, 2014). The natural mathematics language used by the teacher is modeled by children. In addition to this, in a correct sense, children start to use mathematical skills effectively by choosing the right words (Landsdell, 1999).

It is known that preschool teachers' use of mathematical language is an effective predictor of the academic success of children. The children in preschool period are beginning to notice and discover quantitative relationships in the world around them and, therefore, to use language, painting, modeling and other forms of representation in order to clarify the information they have acquired in mathematical subjects such as numbers, shapes, space etc. (McCray \& Chen, 2012). Therefore, a preschool teacher's task extends beyond introducing mathematics to young children in a classroom environment, naming it and establishing a conceptual understanding of new mathematical operations in order to help them to test these operations. However, the point that teachers need help is to determine what mathematical inputs children need and to determine what kind of formal or informal way they will follow (Kabael \& Baran, 2016).

It is necessary for the teachers to be aware of what concepts and words they use, the meanings of the expressions and the verbal messages they want to give when using mathematical language and to gain an awareness of how they will manage this. The way teachers communicate with children change depending on the whether their activities and practices are formal or informal. Teachers assign their expressions in different types of sentence structures when they are communicating with children. While some reactions contain positive messages, some may have negative implications.

Strategies frequently used in teachers' expressions are giving feedback, correcting, reminding, attracting attention and motivating (Memişoğlu, 2008; Sönmez, 2011). However, teachers also use expanding, accepting, repetition, intervening, providing instructions and asking questions when these strategies are not sufficient in the classroom environment. Although narrating strategy is not appropriate for the characteristics of children in the preschool period, teachers reflect this strategy into their classroom environments (Küçükahmet, 2014). 
The necessity of determining the mathematical language used by the teacher has arisen since basic mathematical skills are based on advanced academic skills for children and at the same time the communication in the classroom environment is considered to have not progressed only in formal form. It is known that the preschool teachers receive training for supporting children's skill acquisition during their undergraduate education. However, the fact that there are differences in the opinions and practices of teachers about natural mathematics language, there is no example of non-formal mathematics learning and they plan activities for limited areas when they are transforming theoretical knowledge into practice constitutes the research question of this study.

When the studies conducted on mathematics were examined, it was seen that the perceptions, attitudes, and competencies were investigated and their opinions on this issue were received, but the natural mathematics language in the classroom environment was not mentioned and there were no studies conducted on this issue. Considering these shortcomings, such a study will contribute to this field in terms of revealing the importance of teachers' use of natural mathematics language and raising awareness on this issue. In the direction of these thoughts, it is aimed to observe the use of natural mathematics language, to take opinions about natural mathematics language and to reveal the similarities and differences between its applications and opinions.

\section{Methodology}

In this study, a qualitative research process and a case study design was used. The reason for choosing a qualitative research method was that it allowed us to observe the phenomenon and behavior in its natural environment and its own context without any other intervention ( Glesne, 2013; Yıldırım \& Şimşek, 2011). It is possible to obtain rich and detailed data in the qualitative research. In case studies, the situation is handled and analyzed as a whole while the answers of how and what questions are sought (Yıldırım \& Şimşek, 2011).

\section{Participants}


The purposeful sampling method was used when choosing the participants of the study group. Unlike other quantitative sampling methods, this sampling method is based on the criteria at the center of this study. Purposeful samples provide participant examples that are rich in terms of knowledge and experience for the researchers (Glesne, 2013). The most important point in purposeful sampling is that the sampling process is based on volunteerism. The criterion chosen with purposeful sampling reflects the aim of the study directly. The size of the sample is shaped by the focus of the study, and the depth, width and amount of obtained data. The sample constitutes a very small part of the population. There are no concerns about the generalization of this study to the whole population. The teachers constituting the study group were sampled as a typical case study. The teachers in the study group share similar characteristics and this makes it easier to reach more realistic results about the population (Yıldırım \& Şimşek, 2011).

The study group of this study consisted of volunteer preschool teachers working in nursery classes of elementary schools and formal independent kindergartens in the central district of Erzurum province, Turkey. The study group consisted of 8 preschool teachers: 5 preschool teachers working in nursery classes of elementary schools and 3 preschool teachers working in formal independent kindergartens. There was only one male teacher in the study group.

Table 1a

The Distribution of Teachers Constituting the Study Group

\begin{tabular}{lll}
\hline Teacher & School type & Study group working hours \\
\hline T1 & $\begin{array}{l}\text { Nursery class within the elementary } \\
\text { school }\end{array}$ & Morning \\
T2 & $\begin{array}{l}\text { Nursery class within the elementary } \\
\text { school }\end{array}$ & Morning \\
& Independent kindergarten & Afternoon \\
T3 & Independent kindergarten & Morning \\
T4 & Independent kindergarten & Morning \\
T5 & Nursery class within the elementary & Morning \\
T6 & school & \\
& Nursery class within the elementary & Afternoon \\
T7 & school & \\
& Nursery class within the elementary & Morning \\
T8 & school & \\
\hline
\end{tabular}

First, teachers participating voluntarily in the study were requested to fill in the Personal Information Form. According to this Personal Information Form, the characteristic of the study group was determined. 
Table $1 b$

Personal Information of the Teachers Participating In This Study

\begin{tabular}{|c|c|}
\hline Teacher's age & $\mathrm{f}$ \\
\hline 23 years old & 1 \\
\hline 27 years old & 1 \\
\hline 30 years old & 2 \\
\hline 32 years old & 1 \\
\hline 33 years old & 1 \\
\hline 35 years old & 1 \\
\hline 39 years old & 1 \\
\hline \multicolumn{2}{|l|}{ Gender } \\
\hline Female & 7 \\
\hline Male & 1 \\
\hline \multicolumn{2}{|l|}{ University } \\
\hline Atatürk University & 4 \\
\hline Selçuk University & 2 \\
\hline 100. Y1l University & 1 \\
\hline Anadolu University (Open & 1 \\
\hline Education Faculty) & \\
\hline \multicolumn{2}{|l|}{ Professional Seniority } \\
\hline 1 year & 1 \\
\hline 5 years & 1 \\
\hline 6 years & 2 \\
\hline 9 years & 1 \\
\hline 10 years & 2 \\
\hline 14 years & 1 \\
\hline
\end{tabular}

\begin{tabular}{ll}
\hline Institution type & $\mathrm{f}$ \\
\hline Nursery class within elementary school & 5 \\
Independent kindergarten & 3 \\
\hline Professional time & 1 \\
\hline 5 months & 2 \\
1 year & 1 \\
2 years & 1 \\
3 years & 1 \\
6 years & 1 \\
9 years & 1 \\
10 years & 2 \\
Age group & 1 \\
6 years old & 2 \\
4-6 years old & 3 \\
5-6 years old & \\
\hline
\end{tabular}

The ages of teachers participating in this study ranged between 23-39. The average of the teachers' ages was found to be 31 . When gender distributions of the teachers are examined, it is seen that there are only 1 male teacher and 7 female preschool teachers in the study group. The teachers participating in this study graduated from the following universities: 4 teachers from Atatürk University, 2 teachers from Selçuk University and the others from 100. Y11 University and Anadolu University. All of the teachers participating in this study completed their undergraduate education in Preschool Teaching Department of related universities.

When the professional seniority degrees of the teachers participating in this study, it is seen that their seniority degrees are in a wide range between 1 year and 14 years. A teacher who has been recently assigned and a teacher who has been teaching for a long time constituted the two endpoints of the study group. The average of professional seniority degrees of this study group was 8 years. It was determined that the professional times of the study group ranged between 5 months and 10 years and the average for this group was 4 years (see Table 1b). 


\section{Data Collection Instruments}

A Video Record Review Form designed for video records, observation record books where research observations are recorded, Personal Information Form for obtaining information about teachers and a semi-structured Natural mathematics language Personal Opinion Determining Form for obtaining teachers' opinions on natural mathematics were used in this study.

The data collection tools were prepared by the researchers of this study by means of receiving appropriate opinions. Video Record Review Form was prepared as a form that included the activities in preschool education curriculum as well as the determined mathematical skills and strategies (MoNE, 2013). The skills determined for video record review form were submitted to expert opinion and final changes were made. Observation Record Books included the researcher's comments on the classroom environments and anecdotes apart from the camera records.

Personal Information Form is a form consisting of questions about the teachers' age, gender, educational status, graduated university, graduated department, professional seniority degree, age group they work with, institution type they work in and their working hours. Natural mathematics language opinion determining form consisted of 10 questions that were prepared by reviewing the related literature, but the number of questions was reduced to 6 after it was analyzed by 3 experts.

\section{Data Collection}

Qualitative methods such as observation, anecdotal records, and interviews were used in order to collect the data related to natural mathematics language that preschool teachers use within the classroom environment.

\section{Pilot study}

A pilot study was conducted in 2014-2015 academic year fall term before starting this study. Camera record and interview were applied to a teacher who was not included in the study group. Some arrangements were made by considering the presence of a camera in the classroom environment, children's reactions, recording videos healthily, taking anecdotal records and 
teacher's concentration and, then, the study was started to be conducted on other teachers. The pilot study was not assessed within the scope of this study.

\section{Observation}

The presence of the researcher during the observation, obtaining the existing data from the primary resource and being able to assess the environment in its own context provides a data richness in remembering and interpreting the events (Yıldırım \& Şimşek, 2011). In order to reveal the natural mathematics language that teachers use in the classroom environment, observations were made by the researcher in the classroom environment with a nonparticipatory observer role. The teachers participating in this study were informed of the basic conditions of the study, camera and voice recordings, but they were not informed of the research subject. The use of a video camera and anecdotal records during the observations make it possible for the data to support each other. Cameras were installed to the classes of teachers who accepted these conditions. The observations started to be conducted in March of 2014-2015 academic year spring term and they were finished in May. Considering the process of getting accustomed to the researcher and in order to ensure that the teachers feel comfortable during the observations in the classroom environment, each teacher was observed for a week before starting to implement the study. The records in this period specified as the adaptation process were not assessed. As the training period of institutions providing half-day training was about 4.5-5 hours, this period was determined as an observation period for each teacher. The teachers participating in this study were observed for a total of 23-25 hours. All educational processes of teachers, their activities (other than mathematical activities) and their conversations with children were also recorded. The researcher did not intervene in the classroom environment or teachers' behaviors under no circumstances. The researcher recorded the general observations and comments in the record book as anecdotal records. When the researcher completed the observations, a total of 185 hours of observations were recorded.

\section{Interview}

Interview, which is another method used within the scope of this study, presents ideas about the interests, attitudes, thoughts, and beliefs of individuals and refers to an interactive process (Yıldırım \& Şimşek, 2011). The most appropriate method and the richest data support is the 
interview questions prepared in a semi-structured form for collecting the opinions of teachers on natural mathematics language. The observation form consisted of two parts: structured personal information form by which teachers' personal information is received and semistructured interview questions involving beliefs and theories related to natural mathematics language. The teachers participating in this study provided in-depth and detailed responses to the questions prepared. After the number of observations for each teacher is completed, interviews related to the natural mathematics language were made. During these interviews, the teachers were informed of the aim of the study. Before the interview forms were applied to the teachers, they were requested to confirm these forms informing that their responses could be recorded with voice recording devices. The interviews were completed with the help of a voice recording device in an appropriate class in a school environment or in an empty area arranged as a game room by getting appointments with teachers. The interviews with teachers lasted approximately 10-15 minutes. A total of 90 minutes of interview data were collected.

\section{Data Analysis}

The collected observation and anecdotal records and responses provided to interview questions were transferred to a computer environment. The Observer XT - Noldus software was used for the analysis of video observations. In this study, Noldus software was chosen because it has the ability to capture and select predetermined behaviors in videos uploaded on the software and it is a utility package program used in qualitative research and behavior analysis. On the other hand, a descriptive analysis method was used in interviews with teachers. The responses to the interview questions were brought together under common themes determined by the researchers. When conducting the analyses and obtaining the final findings, the same datasets were coded by both researchers at different times and a special attention was paid to the fact that both researchers reached a consensus for each data set.

The differences and similarities between application-oriented natural mathematics language used by teachers and interview questions they responded in the light of their existing knowledge were determined. 


\section{Findings}

All teachers participating in this study, which aimed at comparing the opinions of preschool teachers' on their use of natural mathematics language and their practices, was coded from T1 to T10 in line with the observation order. The related literature on the mathematical skills used by teachers during observations was reviewed and 16 mathematical skills were determined. These 16 mathematical skills were collected under the following themes (Ginsburg, Lee, \& Boyd, 2008; Klibanoff et al., 2006):
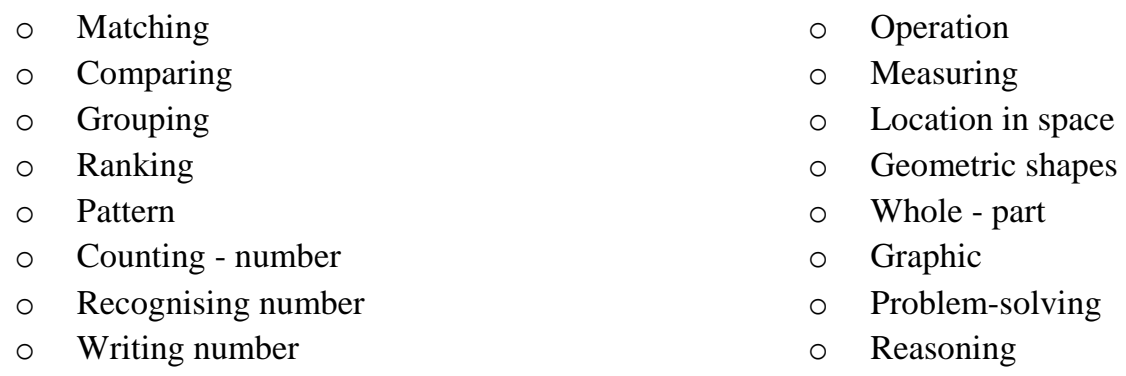

In addition to this, 13 strategies that teachers used for mathematical skills were determined and these were taken into account during the coding process (as cited in Sonnenschein, Thompson, Metzger, \& Baker, 2013):

$\begin{array}{cl}\circ & \text { Reinforcing } \\ \circ & \text { Giving feedback } \\ \circ & \text { Correcting } \\ \circ & \text { Reminding } \\ \circ & \text { Drawing attention } \\ \circ & \text { Motivating } \\ \circ & \text { Narrating - Explaining }\end{array}$

$\begin{array}{ll}\circ & \text { Asking questions } \\ \circ & \text { Extending } \\ \circ & \text { Accepting } \\ \circ & \text { Repeating } \\ \circ & \text { Intervening } \\ \circ & \text { Giving instructions }\end{array}$

During the coding process, it was taken into account in which teacher strategies the expression used for each mathematical skill were included. Only the statements of the teacher were taken into account in this process. It was seen that the number of values was higher than the number of teachers when coding the expression as there was found to be more than one strategy provided by the teacher. 


\section{The Findings Related to the Observation of Teachers}

The results of 8 teachers participating in this study were analyzed and the mathematical skills adopted by teachers when using natural mathematics language were presented in Table 2.

Table 2

Mathematical Skills Adopted by the Participant Teachers When Using Natural Mathematics Language

\begin{tabular}{|c|c|c|c|c|c|c|c|c|c|}
\hline $\begin{array}{l}\text { Mathematicat } \\
\text { skills }\end{array}$ & $T 1$ & $T 2$ & $T 3$ & $T 4$ & $T 5$ & T6 & $T 7$ & $T 8$ & TOTAL \\
\hline Counting - number & 84 & 35 & 66 & 33 & 145 & 35 & 42 & 23 & 463 \\
\hline Measuring & 44 & 28 & 39 & 15 & 27 & 28 & 47 & 28 & 256 \\
\hline Location on space & 50 & 19 & 7 & 4 & 12 & 12 & 14 & 3 & 121 \\
\hline Comparing & 41 & 30 & 14 & 8 & 13 & 2 & 7 & 3 & 118 \\
\hline Geometrical shapes & 27 & 6 & 4 & 1 & 16 & - & 3 & 1 & 58 \\
\hline Grouping & 2 & - & 1 & 4 & 7 & 2 & 6 & - & 22 \\
\hline Ranking & - & - & - & - & 6 & - & 7 & 3 & 16 \\
\hline Pattern & 1 & - & - & - & - & 12 & - & - & 13 \\
\hline Recognizing numbers & 2 & 6 & 1 & - & - & 1 & 2 & - & 12 \\
\hline Whole - part & 4 & 1 & 2 & - & - & - & - & 3 & 10 \\
\hline Matching & 2 & - & - & 5 & 1 & - & - & - & 8 \\
\hline Writing numbers & - & 1 & 1 & - & - & 1 & - & - & 3 \\
\hline Operation & 1 & 1 & - & - & - & - & - & - & 2 \\
\hline Graphics & 2 & - & - & - & - & - & - & - & 2 \\
\hline Problem solving & - & - & - & - & - & - & - & - & - \\
\hline Reasoning & - & - & - & - & - & - & - & - & - \\
\hline TOTAL & 261 & 127 & 135 & 70 & 227 & 93 & 128 & 64 & \\
\hline
\end{tabular}

Considering the natural mathematics language expressions used by all teachers, it was seen that all teachers included counting - numbers (n:463), measuring (n:256), location in space (n:121) and comparing (n:118) skills (see Table 2). All teachers except for T6 included geometrical shapes. All teachers except for T2 and T8 observed grouping skill while only T1 and T6 observed pattern skill. Operation skill was included in the expressions of T1 and T2. It was determined that graphic skill was only included in the expressions of T1 while problem-solving and reasoning skills were not included in the expressions of the teachers.

Counting-numbering, measuring, situating and comparing skills that teachers use the most include mathematical concepts that can easily be placed in sentences and expressions in daily life. In addition to this, it should be considered that these skills have subdomains. The professional experiences of teachers and that they work with different age groups did not change this result. It can be said that the number and diversity of mathematical skills used by 
the teachers who provided positive opinions on children that teachers work according to anecdote records were higher.

Some of the examples of expressions related to the mathematical skills used by teachers during the practices are provided below:

Examples of counting numbers skill: "How many family members are there in B's family?" (T1), "Guys, we have two puppets” (T4) and "We have two new toys. Did you see them?" (T5)

Examples on measuring skills of the teachers: "We did that yesterday." (T2), "You have 5 minutes to get ready." (T3) and "I think B got more molds" (T7)

Examples of mathematical skills related to location in space: "Raise your right hand first, and then raise your left hand" (T1), "Jump forward and backward!" (T4) ve "Everybody, drop your water bottles to the right" (T6).

Examples on comparing skill: "You need to find a faster vehicle for yourself, this one is slow" (T2), “There are two types of peppers: some are green and some are red." (T3) and "Girls, pull the rope harder!" (T5).

Examples of mathematical skills related to geometrical shapes: "Let's form a circle again!" (T5), "Please circle that color, too" (T7) and "The geometrical shape you are stepping on is a square, please look carefully!” (T8).

Examples of grouping skill: "I will send you to the washroom to wash your hands by fives, but please be quiet." (T1), and "You are not playing house, I have already told the playhouse group." (T6).

Examples of ranking skills: "B. and Z. finished first, please applaud them." (T5) and "We have three options; 1. Playdough, 2. Bingo and 3. Hopscotch" (T7).

Examples of mathematical skills related to patterns: "The one who has a rectangle, please come here. Then, the one who has a circle, then a triangle and a rectangle, again." (T1) and "Let me 
look at the beads you strung: there are three yellow and three green beads. You can continue like this.” (T6).

Examples of recognizing numbers skill: "The next one will be attached on 9, which one is 9?" (T3), "1-2-3. Give me the next number, is it 4?" (T6) and "A. Do you know which number is this?" (T7).

Examples of mathematical skills related to the whole - part: "Whose half paper is this?" (T2), "It will be better if you paint the half of the house with a different color." (T3) and "You ate easily because you divided it into small pieces.” (T8).

Examples of writing numbers skill: "We have already learned 9, how do we write it? Of course, beginning from the lower part." (T3) and "Now, you are going to write 5 and 6." (T6).

Examples of matching skill: "I said: everyone will get one of these ropes in my hand and will try to tie it to one of the legs of a table." (T1), "Now, partners, hold your hands." (T4) and "Everyone is going to have a CD and a circle" (T5).

An example of operation skill was "Yes, you are caught up B., another lamb was caught. One had already been caught. Let's add." (T1) and an example of mathematical skill related to graphic was "The largest shape in a slice of cake belongs to the largest slice." (T1).

Strategies that eight teachers participating in this study adopted when using natural mathematics language were presented in Table 3. 
Table 3

Strategies Adopted By Participant Teachers When Using Natural Mathematics Language

\begin{tabular}{|c|c|c|c|c|c|c|c|c|c|}
\hline $\begin{array}{ll}\text { Strategies } & \text { Teachers }\end{array}$ & $T 1$ & $T 2$ & $T 3$ & $T 4$ & $T 5$ & T6 & $T 7$ & $T 8$ & TOTAL \\
\hline Giving instructions & 52 & 15 & 10 & 21 & 45 & 17 & 17 & 6 & 183 \\
\hline Drawing attention & 50 & 22 & 19 & 5 & 38 & 7 & 28 & 1 & 182 \\
\hline Giving feedback & 25 & 30 & 31 & 7 & 26 & 17 & 18 & 13 & 167 \\
\hline Asking questions & 24 & 12 & 21 & 5 & 33 & 20 & 14 & 5 & 134 \\
\hline Reminding & 19 & 12 & 12 & 6 & 24 & 10 & 19 & 12 & 114 \\
\hline Narrating - explaining & 21 & 1 & 19 & 7 & 17 & 4 & 10 & 5 & 84 \\
\hline Extending & 29 & 1 & 6 & 7 & 12 & 5 & 4 & 12 & 76 \\
\hline Repeating & 13 & 8 & 3 & 4 & 18 & 9 & 2 & 3 & 60 \\
\hline Reinforcing & 10 & 4 & 3 & 1 & 5 & - & 9 & 2 & 34 \\
\hline Correcting & 7 & 3 & 9 & 1 & 6 & 3 & 1 & 1 & 31 \\
\hline Accepting & 4 & - & 1 & 5 & 1 & 1 & 6 & 1 & 19 \\
\hline Motivating & 3 & 4 & 1 & 1 & 1 & - & - & 1 & 11 \\
\hline Intervening & 3 & - & - & & - & - & - & - & 3 \\
\hline
\end{tabular}

It was determined that teachers mostly used giving instructions (n: 183), drawing attention (n:182) and giving feedback strategies (n: 167). All teachers used nine of the determined strategies. It was determined that T1 used all strategies. Accepting and intervening strategies were not used by T2, reinforcing, motivating and intervening strategies were not used by T6, and motivating and intervening strategies were not used by T7. The example of the intervention strategy is only seen by $\mathrm{T} 1$.

Some of the examples of expressions related to the mathematical skills used by teachers during the practices are provided below:

An example on giving instructions strategy was "Please take this to the back of the desk" (T5) and an example on drawing attention strategy was "I $t$ is a very old cloth, it does not belong to your age" (T8).

An example on giving feedbacks strategy was "Eight of you wanted to play hopscotch, two of you wanted to play bingo and eight of you wanted to play with the dough" (T7) and an example on asking questions skill was "Who can bring me two gillyflowers tomorrow?” (T2). 
An example of reminding strategy "The one who collected the most would take the lead of the row, do you remember?" (T4) and an example on narrating - explaining strategy was "These play doughs are standing in the middle of pencils" (T3).

An example of extending strategy was " 1,2 , 3. They caught 3." (T1), an example of repeating strategy was "How do we call the police? 1-5-5, 1-5-5." (T2) and an example on reinforcing strategy was "I liked the ones who played in the house play center more than those who played in puppet center."

An example on correcting strategy was "Remember, instead of 4-5 chocolates, we are getting only one chocolate" (T8) and an example on accepting strategy was "Mm, yes, both of yours are the same, maybe they are the same brand!" (T4).

An example of intervening strategy was " $M$, can you please eat faster? You are eating slowly" (T1) and an example of motivating strategy was "Yes Z, you did it, you are the best" (T4).

\section{The Findings Related to the Interviews with Teachers}

Semi-structured interviews were examined in order to determine the opinions of teachers on natural mathematics language use. 6 semi-structured questions related to natural mathematics language were addressed to the teachers. The opinions of teachers on these questions were obtained. The following questions were addressed to the teachers during the interviews: whether they have heard the concept of natural mathematics language or not, the connection between mathematical language and daily colloquial language, the effect of mathematical language in learning mathematics, whether they use natural mathematics language, the mathematical concepts they use in classroom environment and whether the children remember these concepts or not.

The findings related to the interviews with teachers were evaluated together with the responses of all teachers for each question. Thus, common and different responses to the questions were revealed.

The first question directed to the participant teachers during the interview process is about whether they have already heard the concept of natural mathematics language and what they 
think about this concept. As well as the teachers who responded to this question as it was described in the literature, there were teachers who guessed it by looking at the meaning of the concept. Six of teachers stated that they had not heard this concept before. Two of the teachers made comments on the meaning evoked by this concept instead of responding whether they heard or not. "I heard it, but I don't know too much about its content. I think it is mathematics that is taught by transferring it to children's' daily lives." (T8). Considering the observational data of T8, who explained the natural mathematics language in his/her response, it is seen that he/she is the teacher who uses natural mathematics language the least (n: 64) (see Table 2). It is thought that this teacher's opinions on natural mathematics language are not reflected in classroom environment. Only one out of six teachers didn't make any comments on this concept after stating that he/she didn't hear it. "No, I didn't hear anything about this concept." (T5). Considering the observational data of T5, who provided this response, it is seen that he/she is the teacher who ranked second (n: 227) among other teachers in terms of using natural mathematics language in the classroom environment. This situation can be interpreted as this teacher does not know the corresponding term for his/her practices in literature. In addition to this, T1 (n: 261), T5 (n: 227) and T3 (n: 135) stated that they did not hear the concept of natural mathematics language but it was determined that they were the ones who used natural mathematics language most frequently in the classroom environment (see Table 2). The fact that teachers using natural mathematics language in classroom environments do not have a clear opinion on this concept while the use of natural mathematics language is not observed in the practices of teachers explaining this concept constitutes an evidence for the contradiction and difference among the opinions and practices of teachers.

When the responses given by the teachers to the question asked about the connection between mathematical language and daily colloquial language, it is seen that all teachers participating in this study suggested that there is a relationship between mathematics and daily life. Considering this question, T4 stated that "We teach children the directions when we tell them to go right or left and we teach the beginning or end when we tell them to wait at the beginning or end of something". It is seen from this response that a connection is established between the mathematical concepts and daily life. T6 stated that

"This is because daily life means mathematics. We use mathematics for everything in our daily life. This is similar to saying the name of geometrical shape we use 
when drawing a sun. Which ones among the shapes they drew are related to geometrical shapes? I think mathematics language is connected to daily language".

The opinions of T6 is the most determinant expression that reflects the opinions of teachers on this subject. The response given by $\mathrm{T} 4$ emphasizes that the mathematical expressions in teachers' instructions are part of everyday life. In addition to this, the response given by T6 emphasize that mathematical language is included in children's activities without mathematics content.

When teachers were asked for their opinions on the effect of natural mathematics language in teaching mathematics, their responses were positive. Regarding this specific question, T4 stated that

"Yes, the use of natural mathematics language has an effect on teaching mathematics. For example, as I said previously, we use the concepts of beginning and end. When conducting reassessment works and distributing books, we tell children to take the third one from the beginning and the second from the end. Therefore, the children learn the meaning of beginning and end."

The response given by $\mathrm{T} 4$ addresses the effect of mathematical language. "It absolutely has an effect. This is because we are trying to teach mathematics by means of games during the preschool period. Therefore, the easiest way to teach mathematics is to provide natural expressions like "three of our friends did not come" (T7). This reply also clarifies this situation. The responses given by T4 and T7 suggest that the presence of natural mathematics language in the classroom environment has a positive effect on children's mathematics learning.

Another question directed to the teachers participating in this study was about whether they use natural mathematics language themselves or not. Regarding this question, two teachers (T1 and T2) stated that they did not use natural mathematics language and two teachers (T7 and T8) stated that they definitely used natural mathematics language. Natural mathematics language usage frequency of $\mathrm{T} 1$ (n: 261), who stated that he/she did not use natural mathematics language, was the highest while the usage frequency of T8 (n: 64), who clearly stated that he/she used natural mathematics language, was the lowest (see Table 2). T4 and T6 initially thought that they used natural mathematics language but they realized that they did not use it during the interviews. Considering the observational results, it was determined that the responses given on the use of natural mathematics language did not match up with the practices. 
When the responses given by teachers to the interview questions are examined, it is seen that they use natural mathematics language, but they say that they do not use it because they do not know it as a concept.

"I did not think I used the natural mathematics language so far. After seeing these questions and thinking for a while, I realized that I used this language and I knew $i t$. We use natural mathematics language when lining up, in rule-based games and other drama activities. We frequently use natural mathematics language in drama activities, you know, when giving way or telling children 'You will go first" or 'You will wait for your turn'. Moreover, we use mathematics in other writing - reading activities. I think we also use it in Turkish language activities." (T4).

This response given by T6 indicates that this teacher is using natural mathematics in the classroom environment. Teacher's thinking about what is happening in the classroom environment is seen as a reminder effect of the questions asked during the interviews. It is observed that teachers need to receive feedback on their practices in the classroom environment, the corresponding terms in literature should be explained to them and they should be informed.

Another question directed at the teachers was about what concepts they used regarding the natural mathematics language. It was seen that all teachers used mathematical skills related to counting numbers, measuring, location in space and comparing. In this regard, T1 stated that

\begin{abstract}
"We are conducting activities about opposite concepts, numbers, problem-solving, creating graphics and comparing. I'm trying to let them count numbers rhythmically. I explain the numbers first. For example, when we say work in groups, they do not know what working in groups means. First, I show them how to group. This is also valid for comparing. They need to compare two things. How are they going to compare these two things? First, we explain them how to make a comparison and, then, we let them compare on their own."
\end{abstract}

It was determined that this teacher used 12 out of 16 mathematical skills and his/her opinions and practices showed consistency. T3 expressed how he/she explained "plus" and "minus" signs that are used for addition and subtraction. T3 showed his/her students "plus" and "minus" signs, talked about their meanings and about in which situations they are used. However, the expression examples of $\mathrm{T} 3$ related to mathematical operations skills were not observed during observations (see Table 2). In addition to this, T6 stated that 
"We are using geometrical concepts; square, triangle, rectangle, and ellipse. We use corner and edge concepts when we are playing games and telling our children to go to the edge or corner of the carpet. When drawing geometrical shapes, we tell them to draw corners and edges. When we are explaining circle, we tell them it is a geometrical shape that does not have an edge or corner."

In his/her response, T6 explained the mathematical concepts that he/she frequently emphasized during play activities. It was determined that T6 showed an example about geometrical shapes in classroom environment during observations. When the responses given by the participant teachers and observational findings are examined together, it was seen that the mathematical concepts teachers mentioned in their opinions were not reflected in the natural mathematics language in the classroom environment. The expressions teachers use during practice differ from their opinions. It is anticipated that teachers are not aware of this difference.

Another issue that was referred to the opinions of teachers was whether children remembered special mathematical words or concepts used in the classroom environment or not. Regarding this specific question, all teachers participating in this study except for T2 stated that the children remembered the special words and concepts used in the classroom environment. T1 stated that "They do not forget easily. They generally remember. I observe them, for example, when we use those words or concepts again. I observe them whether they can answer and remember or not." In his/her reply, T1 emphasized children's remembering skills. It was seen that T1 had many examples (n: 19) on remembering skills (see Table 3). However, T2 stated that "No, I do not think so. I observe this through feedback. When I ask them, they do not remember those words or concepts. I think it should be supported in their home as well. I think I do not observe it in children." In his/her reply, T2 emphasized that children did not provide feedback on the natural mathematics language in the classroom environment. According to the opinions of teachers, reminders were often used in the classroom environment. However, in line with the observational data, it was seen that the usage frequency of reminding strategy ranked fifth among other strategies (see Table 3). The use of natural mathematics language by teachers in the classroom environment makes it easier for children to remember related words or concepts. Hearing a concept or expression again in another environment or context also affects children's remembering skills. 


\section{Discussion and Conclusion}

The practices of preschool teachers related to natural mathematics language were observed and their opinions were received. It was determined that there were similarities as well as differences. The opinions of teachers expressed during interviews were not reflected in the natural mathematics language they used in the classroom environment. In addition to this, contrary to this, teachers showed examples of natural mathematics language expressions in their practices although they stated that they did not use it in the classroom environment.

When the observational results of teachers were examined, it was determined that the usage frequency of natural mathematics language was higher in counting numbers, measuring, location in space and comparing skills. In a study conducted by Taşkın (2013), it was determined that teachers used too many expressions in counting number field, but they used quite limited expressions in measuring field. However, measuring skill ranked the second in this study in terms of frequency. The fact that the concepts of length, area, volume, weight, temperature and time are included as the sub-dimensions in measuring skill and the usage area of these concepts is wider in the classroom environment can be shown as a reason for this situation. In a study conducted by Diaz (2008) with teachers, in which most of the teachers described mathematics as counting numbers, it was concluded that only 3 out of 12 teachers did not use mathematical concepts other than counting. In studies conducted by Bequette (2009), Mc Goron (2010), and Tarım and Bulut (2005), it was revealed that teachers described mathematics as counting-numbers concepts and that counting-numbers skill was the most frequently used mathematical skill. It was emphasized in this study that counting skill was the first-rank mathematical skill and a similar result was observed in a study conducted by Parpucu and Erdoğan (2017).

When the observational results of teachers were examined, it was determined that all teachers except for one showed examples on geometrical shapes. Only one of the teachers provided a strategy example on graphics concept. None of the teachers provided examples on problemsolving and reasoning skills. In studies conducted by Rudd, Lambert, Satterwhite, and Zaier (2008), it was revealed that teachers included spatial concepts more frequently but they used high-level skills less. It is known that all mathematical skills in mathematics teaching during the early childhood period support a different area of children's development. Teaching 
problem-solving and reasoning skills at an early age and providing frequent examples in order to develop these skills constitutes the basis for children to learn life skills. Practicing in the classroom environment, demonstrating them in plays and providing more experience are important steps in acquiring high-level mathematical skills. However, it was determined that teachers were unable to reflect enough practices and expressions related to the natural mathematics language used in the classroom environment.

When the strategies used by teachers were examined, it was determined that the first 5 strategies were giving instructions, drawing attention, giving feedback, asking questions and reminding. Each strategy type was exemplified by at least one teacher. Intervening strategy was used by only one teacher. When the study conducted by Taşkın (2013), it was emphasized that teachers most frequently asked and they chose this strategy to communicate with children. In a study conducted by Brown (2003), it was determined that teachers used giving instructions strategy when teaching mathematics. These findings are in parallel with the findings of this study. It is thought that this strategy, giving instructions strategy, is frequently used when teachers tell children what to do in the classroom environment, direct them towards the activity, practice and task they will perform and give instructions on how to perform these activities. It is thought that reinforcing, motivating and expanding skills needed by preschool children should be used by teachers. When the observational data of teachers are examined, it is seen that they included mathematical expression during or at the beginning of an activity. Teachers' talking about the activities performed at the end of the process will require them to include more expanding and motivating strategies. However, as teachers avoid these situations, there are no examples of strategies in line with children's needs.

Considering the responses provided by teachers to the interview questions, it was determined that 6 teachers stated that they did not hear the concept of natural mathematics language before. Although these teachers stated that they did not hear this concept, they made comments with regard to the lexical meaning of the concept. Only one teacher did not try to guess its meaning. It was determined that teachers did not know natural mathematics language conceptually but they used it in the classroom environment. The questions asked made it possible for them to rethink and review their practices in the classroom environment.

The opinions expressed by teachers during the interviews show differences in the practice results in the classroom environment. It was seen that teachers addressing the importance of 
mathematics language during interviews were unable to reflect this in practice. However, contrary to this, there were more examples of natural mathematics in the observational results of teachers who stated that they did not use any natural mathematics language during the interviews. A similar result was also determined in the studies conducted by Kabael and Baran (2016). It was concluded that the teachers could not reflect their opinions into practice. This conclusion shares similarities with the results that there are differences between the opinions and observational data of teachers (Aydın, 2009; Ernest, 1991; Güven, Karataş, Öztürk, Arslan, \& Gürsoy, 2013). Considering the differences between the opinions and practices of teachers, it is thought that they are lacking related information in the literature. On the other hand, this situation may also be a sign that teachers are not implementing the information they have acquired during their undergraduate education.

It was determined that there were5 teachers using natural mathematics language. In studies conducted by Kabael and Baran (2016) with teacher candidates. It was emphasized that using mathematics language was important and teachers should be models in this regard. In this study, the opinions of teachers suggested that natural mathematics language should be used in the classroom environment. Thus, it is thought that children will adopt mathematics language.

The fact that teachers mentioned that there was a connection between the language used in daily life and mathematical language and the idea that mathematics should be included in daily conversations are supported by the studies conducted by Hur (2010), Kesicioğlu and Alisinanoğlu (2013). In a study conducted by Umay (2003), it was determined that candidate preschool teachers did not regard mathematics as a lesson and it was included in daily life. The responses provided by the teachers in this study also suggested that mathematics should be included in daily conversations. The interaction between mathematics teaching and natural mathematics language is ensured through concrete expressions of teachers, in a natural environment or through experience-containing words. The idea that mathematical language should be used in mathematical teaching is supported by the studies conducted by Taşkın (2013), Sonnenschein and others (2013). Considering mathematics teaching, children need to hear natural mathematics language and they need to see that the teacher uses it. The frequency and quality of the teachers' conversations on mathematics in the classroom environment increase children's mathematical knowledge (Klibanoff et al., 2006). In a study conducted by Frank (2013), it was stated that the mathematical conversations of teachers contributed to the 
analysis and reasoning skills of children. These studies emphasize the importance of natural mathematics language and mathematical conversation. It is important that preschool teachers reflect this in all informal processes not just in the context of mathematical activities in the classroom environment.

When teachers were referring to the mathematical skills, concepts, and expressions during interviews, they mentioned counting numbers, geometrical shapes and operations. According to the observation results, frequently used mathematical skills, concepts or expressions were the words related to counting numbers, measuring and location in space. The fact that teachers mentioned about counting numbers skills during the interviews and that the observational findings were in parallel with this may result from the thought that these skills (the basic skills of mathematics) form the basis for other skills if they are learned by children and reinforced. In studies conducted by Tarım and Bulut (2005), Diaz (2008), Rudd et al., (2008), and Mc Goron (2010), it was revealed that the first concepts spring to mind considering mathematics were numbers and counting. Bequette (2009) conducted a study and mentioned about the frequency of counting and operation skills. However, in this study, operation skill was used by two teachers and ranked thirteenth among 16 mathematical skills. Teachers' frequent emphasis on the areas that can be remembered easily among other mathematical skills increases the likelihood of ignoring their mathematical skills.

\section{Recommendations}

In this study, the opinions and practices of preschool teachers related to the use of natural mathematics language were examined, interpreted and discussed by providing examples from the literature. In line with the conclusions of this study, some recommendations were made.

A study may be planned in order to determine children's mathematics learning in the classes of teachers using natural mathematics language and the influence of mathematical conversation on the mathematics skills of children may be investigated.

It can be recommended that programs can be organized in which mathematical development can be supported with language in order for the preschool teachers to be able to include words, 
concepts, and expressions related to the natural mathematics language in their conversations more consciously.

Workshops can be performed in small groups in order for the teachers to adopt natural mathematics language completely.

Training and courses can be organized in order for the teachers to be more conscious about mathematics teaching and explore other practices around the world.

It can be requested from the preschool teachers that they keep picture books and stories in their classroom environment and benefit from these books more frequently. In addition to this, it can be expected from preschool teachers that they include tongue twisters, songs and plays more. 


\section{References}

Avc1, N., \& Dere, H. (2002, Eylül). Okul öncesi çocuğu ve matematik. V. Ulusal Fen Bilimleri ve Matematik Kongresi'nde sunulan bildiri. ODTÜ, Ankara.

Aydın, S. (2009). Okul Öncesi Eğitimcilerinin Matematik Öğretimiyle Ilgili Düşünceleri Ve Uygulamalarının Değerlendirilmesi (Yayımlanmamış Yüksek Lisans Tezi). Karadeniz Teknik Üniversitesi, Trabzon.

Bali, G. (2002) Matematik öğretiminde dil ölçeği. Hacettepe Üniversitesi Eğitim Fakültesi Dergisi, 23, 57-61.

Bali, G. (2003). Matematik öğretmen adaylarının matematik öğretiminde dile ilişkin görüşleri. Hacettepe Üniversitesi Ĕ̆itim Fakültesi Dergisi, 25, 19-25.

Bequette, S.L. (2009). Kindergarten Students' Exploratory Math Talk With In A Collaboratıve Discourse Community. (Doctor's Thesis). Available from ProQuest Dissertations and Theses database. (UMI No. 3356423).

Boonen, A.J.H., Kolkman, M.E., \& Kroesbergen, E. H. (2011). The relation between teachers' math talk and the acquisition of number sense within kindergarten classrooms. Journal of School Psychology, 49, 281-299.

Brown, E. T. (2003). The influence of teachers' efficacy and beliefs regarding mathematics instruction in the early childhood classroom. Journal of Early Childhood Teacher Education, 26(3), 239-257.

Çetindağ, Z. (2013). Okul öncesi eğitimde iletişim. In G. Uyanık Balat and H. Bilgin (Ed.). Okul Öncesi Eğitimde Sınıf Yönetimi (pp. 203-220). Ankara: Eğiten Kitap.

Diaz, R.M. (2008). The Role of Language in Early Childhood Mathematics (Doctoral Dissertation). Available From Proquest Dissertations and Theses Database. (UMI No: $3319002)$.

Erdoğan, S. (2012). Okul öncesi dönemde matematik programı. In B. Akman (Ed.). Okul Öncesi Matematik Eğitimi (pp. 172-186). Ankara: Pegem Akademi.

Ernest, P. (1991). Mathematics, education and philosophy: An international perspective. London, Washington DC: The Falmer Press. 
Ferrini-Mundy, J. (2000). Principles and standards for school mathematics: A guide for mathematicians. Notices of the American Mathematical Society, 47(8). 868-876.

Frank, J. (2013). The Effects of Using Math Talks to Improve Instruction in a Kindergarten Classroom. (Master's Thesis, St. Catherine University).

Ginsburg, H.P., Lee, J.S., \& Boyd, J.S. (2008). Mathematics education for young children: What it is and how to promote it. Society for Research in Child Development, 22(1). 327.

Glesne, C. (2013). Nitel araştırmaya giriş. In A. Ersoy and P. Yalçınoğlu (Trans.). Ankara: Anı Yayıncılık.

Güven, B., Karataş, İ., Öztürk, Y., Arslan, S., \& Gürsoy, K. (2013). A study of scale development on determination of pre-service and in-service teachers' beliefs about preschool mathematics education. Illkogretim Online, 12(4). 969-980.

Güven, B., Öztürk, Y., Karataş, İ., Arslan, S., \& Şahin, F. (2012, Haziran). Okul öncesi ögretmenlerinin matematik öğrenme ve ögretmeye yönelik inançlarının sınıf ortamına yansımaları. X. Ulusal Fen ve Matematik Eğitimi Kongresinde Sunulan Bildiri, Niğde Üniversitesi, Niğde.

Hur, J.H. (2010). Math Talk Between Preschoolers and their Mothers during a Home Cooking Activity. (Master's Thesis), Purdue University.

Kabael, T.U., \& Baran, A.A. (2016). Matematik öğretmenlerinin matematik dili becerilerinin gelişimine yönelik farkındalıklarının incelenmesi. Illköğretim Online, 15(3), 868-881.

Kesicioğlu, O.S., \& Alisinanoğlu, F. (2013). Okul öncesi dönem çocukların okul dışı (informal) matematik öğrenme süreçlerine ilişkin aile görüşleri. The Journal of Academic Social Science Studies, 6(7), 671-685.

Klibanoff, R.S., Levine, S.C., Huttenlocher, J., Vasilyeva, M., \& Hedges, L.V. (2006). Preschool children's mathematical knowledge: The effect of teacher math talk. Developmental Psychology, 42(1), 59-69.

Kranda, J. (2008). Precise mathematical language: Exploring the relationship between student vocabulary understanding and student achievement. Master's Thesis.

Küçükahmet, L. (2014). Öğretim ilke ve yöntemleri (26. Basım). Ankara: Nobel Akademik Yayıncılık. 
Linder, S.M., Powers-Costello, B., \& Stegelin, D.A. (2011). Mathematics in early childhood: research-based rationale and practical strategies. Early Childhood Education Journal, 39(1), 29-37.

McCray, J.S., \& Chen, J.Q. (2012). Pedagogical content knowledge for preschool mathematics: Construct Validity of a new teacher interview. Journal of Research in Childhood Education, 26(3), 291-307.

Mc Goron, F.X. (2010). Efficacy of Preschool Teacher Math Talk. (Doctoral Dissertation), University of Cincinnati.

MEB, (2013). Okul öncesi eğitim programi. Retrieved 20 October, 2014, from http://Tegm.Meb.Gov.Tr/Dosya/Okuloncesi/Ooproram.

Memişoğlu, S.P. (2008). Sınıf ortamında öğrenme-öğretme sürecinin yönetimi. In M. Çelikten (Ed.), Yapılandırmacı Yaklaşıma Göre Sınıf Yönetimi (pp. 3- 24). Ankara: Anı Yayıncılık.

Moseley, B. (2005). Pre-Service Early childhood educators' perceptions of math-mediated language. Early Education and Development, 16(3), 385-398.

National Association for the Education of Young Children (NAEYC) (2008). Early childhood mathematics: Promoting good beginnings. Washington, DC: NAEYC.

National Council of Teachers of Mathematics (NCTM) (2000). Principles and standards for school mathematics, 70-140.

Parpucu, N., \& Erdoğan, S. (2017). Okul öncesi öğretmenlerinin sınıf uygulamalarında matematik dilini kullanma sıklıkları ile pedagojik matematik içerik bilgileri arasındaki ilişki. Erken Çocukluk Çalışmaları Dergisi, 1(1), 19-32.

Peter-Koop, A., \& Scherer, P. (2012). Early childhood mathematics teaching and learning. Journal für Mathematik-Didaktik, 33(2), 175-179.

Rudd, L.C., Lambert, M.C., Satterwhite, M., \& Zaier, A. (2008). Mathematical language in early childhood settings: What really counts? Early Childhood Education Journal, $36(1), 75-80$.

Sarama, J., Lange, A.A., Clements, D.H., \& Wolfe, C.B. (2012). The impacts of an early mathematics curriculum on oral language and literacy. Early Childhood Research Quarterly, 27(3), 489-502. 
Sonnenschein, S., Thompson, J.A., Metzger, S.R., \& Baker, L. (2013). The relation between preschool teachers' language and gains in low income English language learners' and English speakers' vocabulary, early literacy and math skills. NHSA dialog: A researchto-practice. Journal for the Early Childhood Field, 16, 64-87.

Sönmez, V. (2011). Eğitim felsefesi (11. Baskı). Ankara: Anı Yayıncılık.

Tarım, K. \& Bulut, S. (2005). Okul öncesi öğretmenlerin matematik ve matematik ögrretimine ilişkin algl ve tutumları, In Hüseyin Kıran (Ed.), XIV. Ulusal Eğitim Bilimleri Kongresi (pp.28-30). Pamukkale Üniversitesi.

Taşkın, N. (2013). Okul Öncesi Dönemde Matematik ile Dil Arasındaki Ilişki Üzerine Bir Inceleme. (Yayınlanmamış Doktora Tezi), Hacettepe Üniversitesi, Ankara.

Taşkın, N. \& Tuğrul, B. (2014). Okul öncesindeki çocukların dil ile matematik becerileri arasındaki ilişkinin farklı değişkenlere göre incelenmesi. YYÜ Eğitim Fakültesi Dergisi, $X I(1), 129-148$.

Taştepe, T. (2012). Erken Çocukluk Dönemi Fen ve Matematik Eğitimi Içerik Standartları Değerlendirme Araçlarının Geliştirilmesi. (Yayımlanmamış Yüksek Lisans Tezi), Gazi Üniversitesi, Ankara.

Tuğrul, B. (2002). Erken çocukluk döneminde öğrenmeyi ve öğretimi kolaylaştıran özellikler. Hacettepe Üniversitesi Ĕ̈itim Fakültesi Dergisi, 22(22), 142-147.

Umay, A. (2003). Okul öncesi öğretmen adaylarının matematik öğretmeye ne kadar hazır olduklarına ilişkin bazı ipuçları. Hacettepe Üniversitesi Eğitim Fakültesi Dergisi, 25(25), 194-203.

Uyanık, Ö. \& Kandır, A. (2010). Okul öncesi dönemde erken akademik beceriler. Kuramsal Ĕ̈itim Bilim, 3(2), 118-134.

Yıldırım, A., ve Şimşek, H. (2011). Sosyal bilimlerde nitel araştırma yöntemleri (8. Tıpk1 Basım). Ankara: Seçkin Yayıncılık.

Yıldırım, B. (2012). Matematik ilkeleri ve standartları. In B. Akman (Ed.). Okul Öncesi Matematik Ĕ̈itimi (pp. 12-24). Ankara: Pegem Akademi. 